Vol. 4, No. 1, Tahun 2017

\title{
WATER RESISTANCE OF RECYCLED PAPER PANEL
}

\author{
Alexander Rani Suryandono \\ Teaching staff, Department of Architecture and Planning, Universitas Gadjah Mada \\ E-mail: alexanderrs@ugm.ac.id
}

\section{Dimas Wihardyanto}

Lecturer, Department of Architecture and Planning, Universitas Gadjah Mada

E-mail:wihardyanto@gmail.com,dimas@ugm.ac.id

\begin{abstract}
Recycled paper has many benefits, from saving woods to reducing carbon footprints. Industrialized recycled paper were mainly made in developed countries. These processes are using high technology and utilize chemical reactions and materials that can only be done in large factories. Meanwhile, paper are also used in developing countries. Newspaper is one of the mass medias that use a high number of paper. Printed newspaper are still used by the majority of people which they prefer rather than the digital newspaper version. This paper focuses in newspaper recycling that can be done in a home industry without high technology involved so that the people of developing countries could easily do it. The paper is broken into cellulose and then glued using tapioca starch. The recycled paper is formed as a panel for partition in a house. The recycled panel paper is put into the water to measure the resistance level. This experiment will help to understand the recycled panel paper strength against water. Recycling process in a home industry can be a part of green solution, especially in paper use. Through this experiment method research, it can be seen that recycled paper panel has a certain resistance level from water and may be used for partition panel.
\end{abstract}

Keywords: recycled paper, panel, partition, environmental friendly, building materials

\section{KETAHANAN AIR PANEL KERTAS DAUR ULANG}

\begin{abstract}
Abstrak
Kertas daur ulang memiliki banyak manfaat, mulai dari mengurangi penggunaan kayu sampai karbon. Industri kertas daur ulang banyak terdapat di Negara maju. Proses ini membutuhkan teknologi tinggi dan menggunakan reaksi dan bahan kimia yang hanya mungkin dilakukan di pabrik besar. Sementara itu, kertas juga digunakan di Negara berkembang. Koran adalah satu dari media massa yang menggunakan banyak kertas. Koran cetak masih lebih banyak digunakan daripada media online. Paper ini membahas daur ulang kertas koran yang dapat dilakukan pada skala rumah tangga tanpa teknologu tinggi sehingga dapat dilakukan oleh orang awam di negara berkembang. Kertas koran dihancurkan menjadi selulosa dan menggunakan tepung tapioca sebagai perekat. Kertas daur ulang dibentuk menjadi panel untuk digunakan sebagai dinding partisi. Panel kertas daur ulang ini dimasukkan kedalam air untuk mengetahui ketahan terhadap air. Percobaan ini memperlihatkan tingkat ketahanan panel kertas daur ulang terhadap air. Proses daur ulang yang dapat dilakukan pada rumah tangga dapat menjadi bagian dari solusi hijau, khususnya pada penggunaan kertas. Melalui riset berbasis eksperimen ini, dapat dilihat bahwa panel kertas daur ulang memiliki ketahanan terhadap air dan dapat digunakan sebagai dinding partisi.
\end{abstract}

Kata-kata kunci: kertas daur ulang, panel, partisi, ramah lingkungan, bahan bangunan 


\section{Introduction}

Paper is made from cellulose pulp obtained from wood, rags, or grasses. According to The School of Engineering at Darthmouth (2010) website, the production of 1 metric ton of paper require 24 trees, $25 \mathrm{~m}^{3}$ of water, $10,061 \mathrm{kWh}$ of electricity and $2.57 \mathrm{~m}^{3}$ of oil. Every tree needs $490 \mathrm{~L}$ of water for growth and $189 \mathrm{~L}$ of water for processing into paper Paper is commonly used worldwide for many occasions, from office paper to newspaper and brochures. According to United States recycling statistics which is cited by Wisler (2015), 77\% of half kilograms paper is wasted per employee in a typical office. Most of the paper wasted are high grade paper. Paper industry has many environmental impacts. Some issues related to paper industry are deforestation, air pollution, water pollution, waste, wood pulping process, chlorine based materials, sulfur based materials, and nonrenewable resources.

Trees are harvested to make raw materials for paper industry. More trees cut will create deforestation. Unlike natural forests, replanted trees are not self-sustaining. Deforestation could threaten the environment, such as erosion, animal habitats, and also aesthetics. During the paper making process, air and water pollution are discharged. Nitrogen dioxide, sulfur dioxide, and carbon dioxide are gasses that are emitted during manufacturing. Nitrogen dioxide and sulfur dioxide contribute to acid rain while carbon dioxide is the cause for a atmospheric heating process called the green house effect. Water can bring pollution from paper manufacture such as lignin, and also contain alcohol, chelating agents, and inorganic materials such as chlorates and metal compounds. Sometimes the water color is changed, like what happened in Tarawera Rivers, NZ as stated in Radio New Zealand website (2010). Paper can also become a waste after it is used. Spitzer (2009) writes that in The United States, approximately $40 \%$ of solid waste in landfills is paper and cardboard.

Since the use of paper is inevitable, recycled paper can be one of the solutions to solve the problem about paper industry. Paper can be recycled, even though it has limitations. In general, paper can be recycled up to seven times since it is created in a high grade paper. Paper recycling has many benefits from environment to economic point of view. Recycled paper is environment friendly. According to Blue (2008), recycling paper can save spaces in landfills, energy and water, reduces greenhouse gases and preserving resources. West (2015) writes that in The United States, 65.4\% of paper was recycled, for a total of 51 million tons in 2014. One ton of recycled paper can save 17 mature trees, 7,000 gallons of water, 380 gallons of oil, 3.3 cubic yards of landfill space, and 4,000 kilowatts of energy and reduce greenhouse gas emissions by one metric ton of carbon equivalent. LeBlanc (2016) adds that the paper recovery rate is doubled since 1990 to early 2011. Moreover, recycled paper is also economically profitable. For example: printing on both sides of the paper rather than only on one side. This method of reusing the paper can save cost. Miller (2011) states that recycling paper can create job opportunities too.

This paper aims to explore the possibilities of using recycled paper to create a partition panel. This experiment is not only for dealing with environmental issues but also creating an economic chance in a developing country. Recycled paper is commonly done in developed countries in the manufacturer using high technology tools. In developing countries, a different approach using a low technology can be offered and is probably more suitable within the context. People can recycle paper and use it for themselves. Using a low technology, they can produce it in a small scale home industry.

\section{Newspaper Print}

Newspaper is a kind of mass media which is usually published daily, but sometimes a few media publish it weekly. It informs its reader diverse news, from everyday headlines, until sport and celebrity news. Newspaper is usually a commercial bussiness activity by its publishers, but there are also a few publishers that doesn't use newspaper as a commercial bussiness, like the non-profit 
Philadelphia Media Network as mentioned by Meyer (2016) in the Atlantic website.

Newspaper paper, which is usually called Newspaper print is a low-cost paper consisting mainly of wood pulp. Goyal (2015) in his website paperonweb.com writes that newsprint is usually weighed around 40 to 50 grams for each square meter, far less than bond paper and paperboard which is around 90 to 300 grams each square meter. It has a thickness around 60 to 80 nanometers, less than the usual office paper which is around 110 nanometers. Newsprint is also a kind of paper which is used straightforward without any dyes, so newsprint paper always shows its natural colors.

\section{Partition Panel}

Partition wall is a wall that separates or divides rooms. It is a non-bearing wall, whereas partition panels are single panels that construct a partition wall. The panels are usually unable to stand on its own, therefore an additional structure is needed. Partition panels can be made from a diverse range of materials, ranging from recycled materials such as cardboard, newsprint, paper, to industrial materials such as metal or wood. Partition wall have many functions. One of the function of the partition wall is it can create spaces. Partition wall divides rooms based on its functions or human activities inside. Partition wall can also be used to cover structural components, such as columns. It can also be used to cover leftover space under stairs to create a tidier view. Partition wall can also be made flexible. It can be arranged to create storages. Whenever it is unused, it can be disassembled and moved or stacked to be stored. Partition walls can also be used to increase the aesthethic value of a wall. It can be added or placed to a permanent or structural wall without endangering the building's structure.

This research focuses in water resistance level. Water resistance level is important since the panel will be exposed to a certain degree of water or placed in a damp condition even though it is put inside a building. This experiment will be conducted by putting the panel into the water and measure panel's resistance against water.

\section{Recycled Paper Panel}

The research in this paper is specifically intended to reuse and recycle newspaper. In developing countries, printed newspaper is still used extensively, rather than the digital newspaper version. This kind of paper is considered as the lowest grade since it is usually already recycled (Sukalich, 2016). The paper will not be recycled to be used as a new paper but transformed into a partition panel wall. Thus, the main purpose of this research is to explore the possibilities of recycled paper panel to serve as a partition wall. As for the recycled paper to be able to serve as a partition wall, the water resistance of it needs to be known so that the best outcome and most water resistant partition wall could be made.

\section{Material and Methods}

In this experiment, the main material to create partition walls is recycled paper obtained from newspaper print. There are several reasons of newspaper as the main material. Newspaper print is considered as a low grade paper. It can hardly be recycled into fine paper. Furthermore, it has a low economic value. It can be obtained with a very cheap price. Other materials are water and tapioca flour. Tapioca flour is chosen since it is an organic material which has low or no negative environmental effects. Tapioca flour acts as a bonding agent for the newsprint. Additive material, which acts as glue, is put to make the panel stronger. The additional material is made from boiled water and tapioca flour mixture. This will create a glutinous liquid that serves as glue to bond the pulp better. Several tools are needed during the process, such as buckets, frames, blender, and mesh or screens. There are no special mechanical tools since the process is intended to be done using low technology in a common house in a developing country. There is also a material used only for layering the panel, which is Portland cement. It serves as a strengthening aspect for the panel, not as 
the main structure.

Not to be misinterpreted as papercrete, Recycled paper panel differs from papercrete. Subramani and Angappan (2015) shows that papercrete is a combination of waste paper and concrete, hence papercrate. Papercrete contains 50\%-80\% of waste paper whereas paper panel consists mainly of waste paper, and the Portland cement only serves as a layer. Once every material is available, the panel can be made.

To create the panel, first, the newspaper prints is torn into small pieces. The pieces are put into the water for four weeks to dissolve the paper and to make the paper soft. Then, the paper is put into a blender and crushed into a fairly smooth pulp. Subsequently, the pulp is separated from the water using a colander. The paper is still fairly wet, so it needed to be dried under direct sunlight during daytime for about two weeks to have a maximum dryness. To create the glue, tapioca flour is mixed with water. In this experiments, four ratios between water and tapioca flour are used. All of the ratios are using the same proportion of water which is $1000 \mathrm{~mL}$ ( 1 liter). The first ratio is using 25 grams of tapioca flour. The second one is using 50 grams, and the third one is using 100 grams of tapioca flour. The last ratio is using 200 grams of tapioca with 1 liter of water. This liquid mixture is stirred while boiled on a stove. It has to be keeped stirring until the color of the mixture change from white into a more transparent colour. Once the glue is ready, it is mixed with 2 kilograms of pulp paper.

Glued pulp paper is put into frame with mesh and dried under direct sunlight for about four weeks. The size of the panel is 30 centimeters long, 30 centimeters wide, and has a height of 2 centimeters. The panels also have different thickness, to make a comparation between thick panels (1 $\mathrm{cm})$ and thin panels $(0.5 \mathrm{~cm})$. After the panels dried, half of the panels are covered using a thin layer of Portland cement equally. There are eight experiment objects with different properties. The differences are object's thickness, Portland cement layer, and ratio between tapioca flour and water as a bonding agent. The summary of the research objects can be seen in the table below.

Table 1. Recycled Paper Panel Model

\begin{tabular}{ccccc}
\hline No. & Object Name & $\begin{array}{c}\text { Thickness } \\
(\mathbf{c m})\end{array}$ & $\begin{array}{c}\text { Portland Cement } \\
\text { Layer }\end{array}$ & $\begin{array}{c}\text { Tapioca Flour (gr) : Water } \\
(\mathbf{L})\end{array}$ \\
\hline 1 & A & 1 & no & $100: 1$ \\
\hline 2 & B & 1 & yes & $100: 1$ \\
\hline 3 & C & 1 & no & $50: 1$ \\
\hline 4 & D & 1 & yes & $50: 1$ \\
\hline 5 & E & 0.5 & no & $200: 1$ \\
\hline 6 & F & 0.5 & yes & $200: 1$ \\
\hline 7 & G & 0.5 & no & $25: 1$ \\
\hline 8 & H & 0.5 & yes & $25: 1$ \\
\hline
\end{tabular}

Source: Authors Research, 2016

All of the research objects are put in the water within a 30 minutes' period. The objects then are observed every ten minutes to inspect and check its strength, whether there are any damages like bending and disassembling or not. The penetration of water in these objects are also marked. Since this research is intended for the common people using low technology and equipment in developing countries, all of the experiment sequence is done under an ordinary house condition (normal room temperature around 25 degrees Celsius and normal room pressure around 100kPA or 1 bar). 


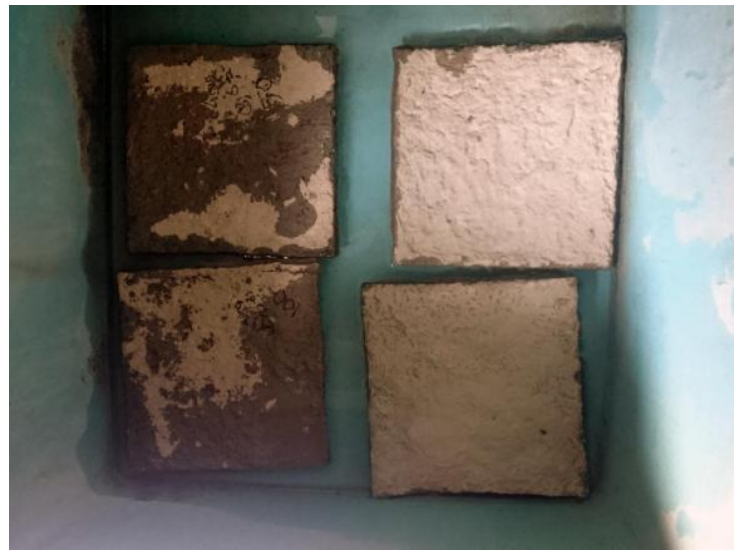

Figure 1. Experiment Objects

Source: Author's Documentation, 2016

\section{Result Analysis}

The experiments conducted above gives result as follows.

Table 2. Experiment Results

\begin{tabular}{lcl}
\hline No. & Object Name & \multicolumn{1}{c}{ Notes } \\
\hline 1 & A & Wet after 4 minutes. Minor bend after 20 minutes. \\
\hline 2 & B & Wet after 14 minutes. No minor bend after 30 minutes. \\
\hline 3 & C & Wet after 4 minutes. Minor bend after 20 minutes. \\
\hline 4 & D & Wet after 8 minutes. No minor bend after 30 minutes. \\
\hline 5 & E & Wet after 2 minutes. Completely damaged after 10 minutes. \\
\hline 6 & F & Wet after 6 minutes. Completely damaged after 10 minutes. \\
\hline 7 & G & Wet after 3 minutes. Completely damaged after 10 minutes. \\
\hline 8 & H & Wet after 4 minutes. Completely damaged after 10 minutes. \\
\hline
\end{tabular}

Source: Authors Experiment, 2016

From the results of the experiment, it can be seen that the objects $\mathrm{E}$ to $\mathrm{H}$ which has a thickness of 0.5 centimeters couldn't withstand water exposure for more than 10 minutes and all of these objects are completely disassembled. The thicker panels (1 centimeter thick), however, has a significant variation of results. All of the panels are capable to resist water for more than 20 minutes, even though the objects A and C (panels without Portland cement layer coating) has minor bends. But the panels with Portland cement layer coating has better water resistance, where the cement layer prevents water to soak into the panel. The object B can resist water for 14 minutes long before it goes wet, and the object D can resist for 8 minutes, where both shows no significant damage unlike object $\mathrm{A}$ and $\mathrm{C}$. The only difference between the object $\mathrm{B}$ and $\mathrm{D}$ is the ratio of the tapioca flour and water. The object $\mathrm{B}$ which has a longer resistance time has a ratio between the tapioca flour and water for 100 grams of tapioca and 1 liter of water. Unlike the object D which has a ratio of 50 grams of tapioca flour and 1 liter of water, the 100 to 1 ratio is more concentrated thus givint it more strength and water resistance capability. 


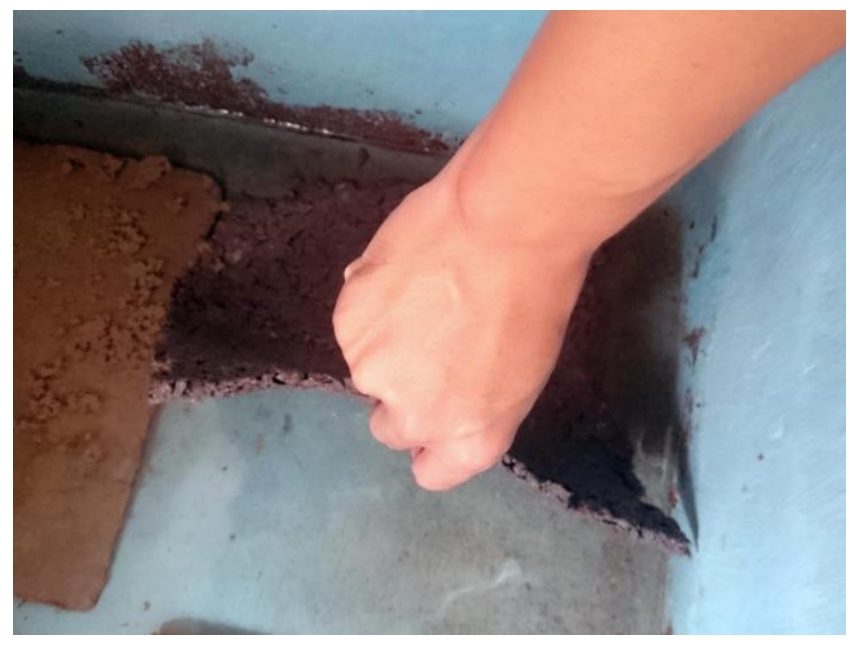

Figure 2. Complete Damage of $0.5 \mathrm{~cm}$ Thickness Recycled Paper Panel Source: Author's Documentation, 2016

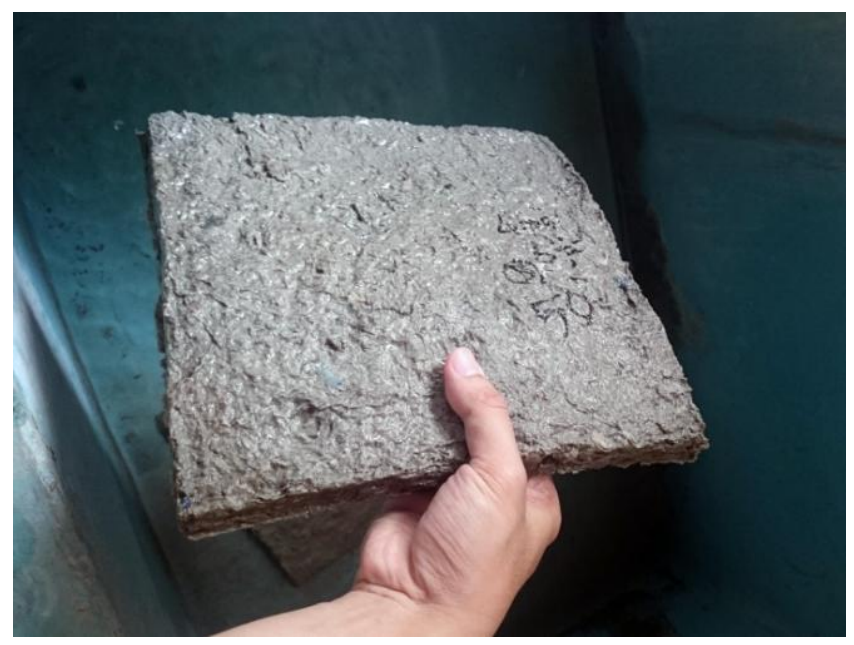

Figure 3. Bending on $1 \mathrm{~cm}$ Thickness Recycled Paper Panel without Cement Layer Source: Author's Documentation, 2016

\section{Conclusion}

Recycled paper panel, even though made from newspaper which is one of the worst paper quality, has possibility to be used as partition wall. From the results, it can be concluded that:

- If Compared to object A, Object B has $350 \%$ more water resistance time (14 minutes to 4 minutes) and $150 \%$ more strength (30 minutes to 20 minutes).

- Object $\mathrm{B}$ has the similar comparison result to object $\mathrm{C}$ as object $\mathrm{A}$, since object $\mathrm{C}$ and $\mathrm{A}$ has the same properties.

- Compared to object $\mathrm{D}$, object $\mathrm{B}$ has $175 \%$ more water resistance time (14 minutes to 8 minutes), and same strength properties (both has no minor damage for after 30 minutes).

- Compared to object E, object B has 7 times (700\%) more water resistance time (14 minutes to 2 minutes), and at least $300 \%$ more strength (30 minutes to 10 minutes). Object $\mathrm{E}$ was completely damaged after 10 minutes, whereas object B is still intact after 30 minutes. Thus, a higher number of the strength property is highly possible.

- Compared to object F, object B has $233,34 \%$ more water resistance time (14 minutes to 6 
minutes) and at least $300 \%$ more strength (30 minutes to 10 minutes). Same as the comparison to object $\mathrm{E}$, a higher number of the strength property is highly possible.

- Compared to object $\mathrm{G}$, object $\mathrm{B}$ has $466,67 \%$ more water resistance time (14 minutes to 3 minutes) and at least $300 \%$ more strength (30 minutes to 10 minutes). Same as the comparison to object $\mathrm{E}$ and $\mathrm{F}$, a higher number of the strength property is highly possible.

- Compared to object $\mathrm{H}$, object $\mathrm{B}$ has $350 \%$ more water resistance time (14 minutes compared to 4 minutes) and at least 300\% more strength (30 minutes to 10 minutes). Same as object E, F, and $\mathrm{G}$, a higher number of the strength property is highly possible.

- Recycled paper panel with thickness of $1 \mathrm{~cm}$ is more capable to withstand water exposure than the panel with a thickness of $0.5 \mathrm{~cm}$ by more than 30 minutes long.

- The Portland cement layer coating of recycled paper panel does not only prevent water soaking and penetration, but also strengthens the structure of the panel itself.

- Water and tapioca flour ratio gives a significant effect on the panel's capability to resist water exposure, and based on this experiment, the ratio of 100 grams of tapioca flour and 1 liter of water gives the most water resistance.

\section{Future research suggestions}

From this experiment, there are several possible further researches that can be done to obtain a more holistic, comprehensive, and valid data.

\section{Based on material's strength:}

1. Research on optimum tapioca flour strength to bond the recycled paper. This research can also be developed to know the possibilities of tapioca flour as glue for other materials, such as: coconut shell, wood, and other organic materials (for environment-friendly considerations)

2. Research on optimum dry time for recycled paper panel. Experiment objects can be tested and take average dry time in relation with strength

3. Research on material shrinkage after dry. When the research object is wet, the size is slightly larger than the object in a dry condition.

\section{Based on material's physical properties:}

1. Research on aesthetics of the recycled paper. This research can be developed into combination among environment-friendly materials, such as leaves, branches, coconut shells, wood, etc

2. Research on material's flexibility. Since the basic shape of recycled paper panel is pulp, it is highly flexible and is able to be formed and shaped by the authors' ideas, especially in terms of Architecture.

3. Research on recycled paper panel's resistance from fire, heat, and sound. Theoretically, paper is a good heat and sound insulation but prone to fire. These future researches can contribute to the knowledge of recycled materials for Architecture.

There are also a number of researches that can be done for environment-friendly materials that is considered as a waste using low technology, i.e.: clay, mud, wood, coconut shells, leave, etc. Limited information in home-made materials, not industrial or factory made materials. These researches can be done in an ordinary house especially in developing countries and has a possibillity to contribute to the global waste reduction.

\section{References}

Alice Wisler (2015) Facts about Recycling Paper. http://greenliving.lovetoknow.com/Facts_About Recycling_Paper. Accessed 2 April 2016

Clay Miller (2011) 5 Benefits of Recycling Paper. http://www.ways2gogreenblog.com/2011/09/28/ 5-benefits-of-recycling-paper/. Accessed 10 May 2016

Hari Goyal (2015) Grades of Paper. 
http://www.paperonweb.com/grade.htm.

Accessed 2 April 2016

Hari Goyal (2015) Properties of Paper. http://www.paperonweb.com/paperpro.htm. Accessed 2 April 2016

Kathryn Sukalich (2016) Everything You Need to Know about Paper Recycling. http://earth911.com/business-

policy/business/paper-recycling-details-basics/. Accessed 15 July 2016

Larry West (2015) Why Recycle Paper. http://environment.about.com/od/recycling/a/The -Benefits-Of-Paper-Recycling-Why-RecyclePaper.htm. Accesed 15 June 2016

Marie-Luise Blue (2008) The Advantages of Recycling Paper.

http://education.seattlepi.com/advantagesrecycling-paper-3440.html. Accessed 15 June 2016

Nina Spitzer (2009) http://www.sheknows.com/homeand-gardening/articles/810025/the-impact-ofdisposable-coffee-cups-on-the-environment. Accessed 15 June 2016

Radio New Zealand (2010) Iwi not Giving Up Fight against Tasman Mill Discharges. http://www.radionz.co.nz/news/regional/64521/i

wi-not-giving-up-fight-against-tasman-milldischarges. Accessed 15 July 2016

Rick LeBlanc (2016) Paper Recycling Facts, Figures and Information Sources. https://www.thebalance.com/paper-recyclingfacts-figures-and-information-sources2877868?_ga $=1.192832942 .544061388 .1477446$ 686. Accesed 2 April 2016

Robinson Meyer (2016) Will More Newspapers Go Nonprofit?

http://www.theatlantic.com/technology/archive/2 016/01/newspapers-philadelphia-inquirer-dailynews-nonprofit-lol-taxes/423960/. Accessed 3 August 2016

School of Engineering at Darthmouth (2010) Forest and Paper Industry. http://engineering.dartmouth.edu/ d30345d/cour ses/engs171/Paper.pdf. Accessed 2 April 2016

T. Subramani, V. Angappan. (2015). Experimental Investigation of Papercrete Concrete. International Journal of Application or Innovation in Engineering and Management. Volume 4 Issue 5 page 134-143 